\title{
Hearing thresholds in adult Nigerians with diabetes mellitus: a case-control study
}

\section{Jones Ndubuisi Nwosu Ethel Nkechi Chime}

Department of Otorhinolaryngology, College of Medicine, University of Nigeria, Enugu Campus, Enugu, Nigeria

This article was published in the following Dove Press journal: Diabetes, Metabolic Syndrome and Obesity:Targets and Therapy 2 May 2017

Number of times this article has been viewed

Correspondence: Jones Ndubuisi Nwosu Department of Otolaryngology, College of Medicine, University of Nigeria Teaching Hospital, Ituku-Ozalla, Enugu, Nigeria. P.M.B OI I29, Enugu, Nigeria Tel +2347039732600

Email jones.nwosu@unn.edu.ng
Objectives: To determine the prevalence, types and severity of hearing loss and associated factors in a hospital population of adult Nigerians with diabetes mellitus.

Subjects and methods: This study was a prospective hospital-based study conducted at the Otorhinolaryngology and Diabetic Clinics of the University of Nigeria Teaching Hospital (UNTH) Ituku-Ozalla, Enugu, for a period of 12 months. Consecutively presenting eligible adult diabetics and their age- and sex-matched healthy controls were recruited. Each case and control participant had clinical and otologic examination, followed by pure tone audiometry. Data were analyzed using descriptive and comparative statistics.

Results: There were 224 patients and 192 control participants. The patients comprised 112 males and 112 females (sex ratio=1:1), whose mean age was 47.6 years (range: $26-80$ years). The prevalence of hearing loss was $46.9 \%$. This comprised $43.8 \%$ sensorineural and $3.1 \%$ conductive hearing losses. The distribution of hearing loss by severity was mild $25.0 \%$, moderate $15.6 \%$ and severe $6.3 \%$. The controls comprised 96 males and 96 females whose mean age was 44.6 years (range: $25-79$ years). The prevalence of hearing loss was significantly higher overall and by type (sensorineural hearing loss, conductive hearing loss) in cases compared with controls. Conclusion: The prevalence of hearing loss among diabetic adults at UNTH, Enugu, is comparatively high. Hearing loss is predominantly sensorineural and often mild to moderate in severity. Routine audiometric evaluation of all adult diabetics at UNTH is recommended.

Keywords: adults, diabetes mellitus, hearing threshold

\section{Introduction}

Diabetes mellitus (DM) is a disease characterized by hyperglycemia due to absolute or relative deficiency of insulin. ${ }^{1}$ Sustained hyperglycemia is associated with multisystemic complications and multiple end-organ damage. Currently, there is a worldwide pandemic of $\mathrm{DM}^{1-3}$ and by extension, the inherent complications.

The auditory apparatus is one of the vulnerable end organs in DM due to ischemic cochlear damage resulting from diabetic microangiopathy. ${ }^{4-6}$ DM-related hearing loss is a major public health issue in both low- and middle-income countries and the developed economies. With the projected increase in the world's diabetes burden due to increased longevity and changes in lifestyle, its prevalence is bound to increase. It impacts adversely on the patients' quality of life and their capacity for independent living.

Previous studies investigating hearing thresholds in DM, in Nigeria ${ }^{7-9}$ and elsewhere, ${ }^{10-16}$ have been dominated by descriptive cross-sectional surveys, often with widely variable results. The reported prevalence of hearing loss ranges from 
$0.0 \%$ to $90.0 \%$. Consequently, the investigators conducted a hospital-based case-control audiometric evaluation of adult Nigerians with and without DM to determine the prevalence, types and profile of hearing loss and the associated characteristics. In addition to provision of valid comparative data, the generated data will assist public health policymakers and implementers, and otologic care providers in optimizing the quality of life of persons living with DM.

\section{Significance of the study}

DM is a systemic disease with multiple systemic complications and end-organ damage. DM-related hearing loss and its adverse impact in the quality of life is a major public health issue across the globe. The study would provide valid comparative data that will assist public health policymakers and otologic care providers in optimizing the quality of life of persons living with DM.

\section{Subjects and methods Background}

Established in 1970 and located in Enugu, southeastern Nigeria, the University of Nigeria Teaching Hospital (UNTH) is one of the first-generation public tertiary health care facilities in Nigeria. UNTH provides undergraduate and postgraduate medical training, outpatient/inpatient clinical care and undertakes research. At UNTH, the otorhinolaryngology (synonym: Ear Nose and Throat [ENT]) department provides medical, surgical and audiometric ENT care, while a dedicated Diabetic Unit, in the hospital's Internal Medicine Department, provides inpatient and outpatient diabetic care. The UNTH's feeder population comprises inhabitants of Nigeria's southeast geopolitical zone and beyond.

The study, conducted for 1 year at the ENT and Diabetic Clinics of UNTH, was a prospective case-control study of eligible diabetic adults and their age- and sex-matched healthy controls.

\section{Ethics}

Prior to commencement of the study, ethics clearance was obtained from the Medical and Health Research Ethics Committee (Institutional Review Board) of UNTH, Enugu, compliant with the tenets of the 1964 Helsinki Declaration on research involving human subjects. Additionally, written informed consent was obtained from each participant, case, and control, before recruitment into the study.

\section{Eligibility cases}

Adults aged 19 years or older diagnosed with types 1 or 2 DM for 5 years or longer, showing absence of congenital anomalies of, or infective/inflammatory/neoplastic lesions of the outer, middle or inner ear were included in the study. Also excluded were potential participants who had coexisting tuberculosis, syphilis, sickle cell disease, hypertension, Human Immune Deficiency Virus infection, neoplasia; or with past history of head injury, acoustic trauma, ear surgery, familial deafness and use of ototoxic drugs 1 month prior to recruitment.

\section{Controls}

Age- and sex-matched healthy nondiabetic adults without any of the above conditions contraindicating enrollment were recruited from the hospital community.

\section{Sample size and sampling technique}

A minimum sample size for the study was calculated using Fisher's formula. ${ }^{17}$ Consecutively presenting patients who met the inclusion criteria were recruited into the study.

\section{Study instrument}

This was a pretested investigator-administered questionnaire/ proforma specifically designed for the study. It contained subsections on participants' demographic and clinical characteristics, and findings of audiometric assessment.

\section{Study procedures}

A peripheral venous blood sample was obtained for fasting blood sugar determination using AccuCheck ${ }^{\mathrm{TM}}$ (Roche Diagnostic GmbH, Mannheim, Germany) and human immune deficiency virus 1 and 2 screening test with Determme

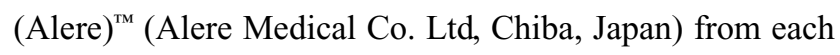
case and control participant. A midstream urine sample was also obtained for urinalysis.

Subsequently, each subject (case and control) had a general and systemic examination, and otologic examination using Led Head light (Tiger Head Battery Group Co., Ltd, Guangzhou, People's Republic of China) and a batterypowered otoscope (Welch Allyn Inc., Skaneateles Falls, NY, USA). Any impacted wax in the external auditory canal was removed either with wax hook (Downs Surgical, Sheffield, UK) or by instilling wax softening solution - Cerumol (Thornton \& Ross Ltd, Huddersfield, UK) before syringing with Higginson's syringe (Downs Surgical) filled with normal saline (Juhel Pharmaceuticals, Awka, Nigeria) at body temperature. This was followed by a re-examination of the ears 
to confirm that the external auditory canal was clear. Pure tone audiometry, in a sound-treated room, using MEDIMATE 602 audiometer (Madsen Electronics, Taastrup, Denmark) calibrated to ISO standard (9002) was performed on each subject to determine the hearing threshold for octave frequencies $250-8000 \mathrm{~Hz}$. The level of hearing for each subject was determined based on pure tone audiometric finding. The average for each frequency considered was determined, and the degree of hearing loss for each patient was determined based on the World Health Organization standard classification $^{18}$ (Table 1).

\section{Data analysis}

Data were entered into and analyzed using the Statistical package for Social Sciences for Windows, version 18 (SPSS Inc., Chicago, IL, USA). Descriptive statistics yielded frequencies, percentages and proportions. Comparative statistical tests for significance of observed intergroup differences were performed using Pearson's chi-square test or Fisher's exact test for categorical variables and Student's $t$-test for continuous/metric variables. In all comparisons, a $p$ value $<0.05$, at one degree of freedom, was considered statistically significant.

Table I WHO grading of hearing impairment as modified in 1991

\begin{tabular}{|c|c|c|c|}
\hline $\begin{array}{l}\text { Grade of } \\
\text { impairment }\end{array}$ & $\begin{array}{l}\text { dBHL corresponding } \\
\text { audiometry ISO } \\
\text { value (average } \\
\text { of } 500,1000 \text { and } \\
2000 \mathrm{~Hz} \text { ) }\end{array}$ & Description & Performance \\
\hline 0 & $\leq 25$ & $\begin{array}{l}\text { No } \\
\text { impairment }\end{array}$ & $\begin{array}{l}\text { No (or very slight) } \\
\text { hearing problem, } \\
\text { able to hear } \\
\text { whisper at I m }\end{array}$ \\
\hline I & $26-40$ & $\begin{array}{l}\text { Slight } \\
\text { impairment }\end{array}$ & $\begin{array}{l}\text { Able to hear and } \\
\text { repeat words } \\
\text { spoken in normal } \\
\text { voice at I m }\end{array}$ \\
\hline 2 & $4 I-60$ & $\begin{array}{l}\text { Moderate } \\
\text { impairment }\end{array}$ & $\begin{array}{l}\text { Able to hear and } \\
\text { repeat words } \\
\text { using raised voice } \\
\text { at I m }\end{array}$ \\
\hline 3 & $61-80$ & $\begin{array}{l}\text { Severe } \\
\text { impairment }\end{array}$ & $\begin{array}{l}\text { Able to hear } \\
\text { some words } \\
\text { when shouted } \\
\text { into the better } \\
\text { ear }\end{array}$ \\
\hline 4 & $\geq 81$ & $\begin{array}{l}\text { Profound } \\
\text { impairment } \\
\text { including } \\
\text { deafness }\end{array}$ & $\begin{array}{l}\text { Unable to hear } \\
\text { and understand } \\
\text { even shouted } \\
\text { voice }\end{array}$ \\
\hline
\end{tabular}

Abbreviations: $\mathrm{dBHL}$, decibels hearing level; ISO, International Organization for Standardization; WHO, World Health Organization.

\section{Results}

Two hundred and thirty cases were recruited in the study; however, six cases with incomplete data were excluded from the analysis.

The participants $(\mathrm{N}=416)$ comprised 224 cases and 192 controls. The cases consisted of $112(50.0 \%)$ males, while their control counterparts consisted of $96(50.0 \%)$ males. The cases were aged 47.6 \pm 10.9 standard deviation (SD) years (range: $26-80$ years), while the controls were aged $44.6 \pm 12.8$ SD years (range: 25-79 years; Table 2). Both groups differed significantly in age (diabetics vs controls: $47.5 \pm 10.9$ vs $44.6 \pm 12.8, t=2.5927, p<0.0099)$. The mean fasting blood sugar of the cases was significantly higher than that of controls $(175.3 \pm 75.6$ vs $76.59 \pm 10.77 \mathrm{mg} / \mathrm{dL}, t=7.31, p<0.05)$.

The prevalence of hearing loss was $46.9 \%$ among cases and $15.6 \%$ in controls. The patient-control age match with hearing threshold is shown in Table 3. Of the cases, normal hearing was present in 119 (53.1\%), sensorineural hearing loss (SNHL) in 98 (43.8\%) and conductive hearing loss (CHL; air-bone gap $\geq 15 \mathrm{~dB}$ ) in 7 (3.1\%); among the controls, hearing was normal in $162(84.4 \%)$, SNHL was present in $30(15.6 \%)$ and $\mathrm{CHL}$ in $0(0.0 \%)$. None $(0.0 \%)$ of the case or control participants had mixed hearing loss. The profile of hearing loss is shown in Table 4.

The diabetic patients consistently had significantly higher mean threshold values at all frequencies in both ears (Table 5). The prevalence of hearing loss was significantly higher overall $(p<0.0001)$ and by type (SNHL, $p<0.0001$; CHL, $p=0.0168)$ in diabetics compared with controls. Figure 1 shows the audiogram of the mean hearing thresholds of DM patients and the controls.

\section{Discussion}

There was equal sex dominance among the case and control participants, which comprised adult participants. This is

Table 2 Age distribution of diabetes mellitus patients and controls

\begin{tabular}{lll}
\hline Age group, years & $\begin{array}{l}\text { Number of patients } \\
(\%), \mathbf{n = 2 2 4}\end{array}$ & $\begin{array}{l}\text { Number of controls } \\
\text { (\%), } \mathbf{n = 1 9 2}\end{array}$ \\
\hline $25-34$ & $7(3.1)$ & $30(15.6)$ \\
$35-44$ & $49(21.9)$ & $42(21.9)$ \\
$45-54$ & $105(46.9)$ & $60(31.3)$ \\
$55-64$ & $42(18.8)$ & $30(15.6)$ \\
$65-74$ & $14(6.3)$ & $24(12.5)$ \\
$75-84$ & $7(3.1)$ & $6(3.1)$ \\
Total & $224(100.0)$ & $192(100.0)$ \\
Mean & 47.56 & 44.56 \\
SD & 10.92 & 12.76 \\
Range & $26-80$ & $25-79$ \\
\hline
\end{tabular}

Abbreviation: SD, standard deviation. 
Table 3 Patient-control age match with hearing threshold

\begin{tabular}{|c|c|c|c|c|c|c|}
\hline \multirow[t]{2}{*}{$\begin{array}{l}\text { Age group, } \\
\text { years }\end{array}$} & Number & Number & \multirow{2}{*}{$\begin{array}{l}\text { Mean of hearing } \\
\text { threshold in dB } \\
\text { Patient }\end{array}$} & \multirow{2}{*}{$\begin{array}{l}\text { Mean of hearing } \\
\text { thresholds in dB } \\
\text { Control }\end{array}$} & \multirow{2}{*}{$\begin{array}{l}\text { Statistics } \\
\text { t-value }\end{array}$} & \multirow{2}{*}{$\begin{array}{l}\text { Statistics } \\
p \text {-value }\end{array}$} \\
\hline & Patients n=224 & Controls $n=192$ & & & & \\
\hline $25-34$ & 7 & 30 & 18.22 & 14.29 & 0.77 & $>0.05$ \\
\hline $35-44$ & 49 & 42 & 18.57 & 13.93 & 1.84 & $>0.05$ \\
\hline $35-44$ & 105 & 60 & 22.86 & 14.64 & 2.50 & $<0.05$ \\
\hline $45-54$ & 42 & 30 & 26.71 & 19.93 & 1.89 & $>0.05$ \\
\hline $55-64$ & 14 & 24 & 45.54 & 22.88 & 1.97 & $>0.05$ \\
\hline $75-84$ & 7 & 6 & 27.50 & 10.72 & 0.82 & $>0.05$ \\
\hline
\end{tabular}

Table 4 Frequency distribution of pure tone audiogram among study participants

\begin{tabular}{llll}
\hline Pure tone audiogram type & $\begin{array}{l}\text { Patients, } \\
\mathbf{n = 2 2 4}\end{array}$ & $\begin{array}{l}\text { Controls, } \\
\mathbf{n = 1 9 2}\end{array}$ & $\begin{array}{l}\text { Total (\%), } \\
\mathbf{N = 4 1 6}\end{array}$ \\
\hline Normal PTA finding & 119 & 162 & $281(67.5)$ \\
Sensorineural hearing loss & 98 & 30 & $128(30.8)$ \\
Conductive hearing loss & 7 & 0 & $7(1.7)$ \\
Mixed hearing loss & 0 & 0 & $0(0.0)$ \\
Total (\%) & 224 & 192 & $416(100.0)$ \\
\hline
\end{tabular}

Abbreviation: PTA, pure tone audiometry.

similar to the demographic profile in the study of Ologe and Okoro, ${ }^{8}$ but differs from the report by Lasisi et al ${ }^{7}$ who had both children and adults as their study participants. The marginal age discrepancy between case and control participants, despite measures to achieve perfect age match, suggests that the age-determined influences on hearing threshold might partly account for the higher prevalence of hearing loss among diabetics. To eliminate the potential cofounding influence of age, related future studies should aim at perfect age match between cases and controls.

In this study, the prevalence of hearing loss, predominantly SNHL and CHL, was significantly higher among cases $(46.9 \%)$ than controls $(15.6 \%)$. There has been a wide variation in the prevalence of SNHL found in studies involving diabetic patients. Ranges such as $0 \%-93 \%{ }^{19,20}$ have been quoted. There has not been any satisfactory explanation for this wide variation. The present finding is consistent with reports elsewhere $(0 \%-93.0 \%),{ }^{19,20}$ but far

Table 5 Comparison of hearing thresholds between cases and controls at all frequencies

\begin{tabular}{|c|c|c|c|c|c|c|c|c|}
\hline \multicolumn{9}{|c|}{ Frequency hearing level (dB) } \\
\hline \multirow[t]{2}{*}{$\mathrm{Hz}^{*}$} & \multicolumn{4}{|c|}{ Right ear (mean \pm standard deviation) } & \multicolumn{4}{|c|}{ Left ear (mean \pm standard deviation) } \\
\hline & Case & Control & $t$ & p-value & Case & Control & $\boldsymbol{t}$ & $p$-value \\
\hline 250 & $22.50 \pm 9.24$ & $14.53 \pm 8.22$ & 9.2254 & $<0.0001$ & $22.66 \pm 13.32$ & $16.25 \pm 8.13$ & 5.8049 & $<0.0001$ \\
\hline 500 & $21.88 \pm 10.61$ & $13.28 \pm 7.58$ & 9.3671 & $<0.0001$ & $20.78 \pm 11.85$ & $16.72 \pm 9.64$ & 3.7920 & 0.0002 \\
\hline 1000 & $22.97 \pm 10.89$ & $14.53 \pm 5.14$ & 9.8394 & $<0.0001$ & $20.94 \pm 12.47$ & $16.56 \pm 6.65$ & 4.3636 & $<0.0001$ \\
\hline 2000 & $24.69 \pm 10.85$ & $13.44 \pm 6.28$ & 12.6625 & $<0.0001$ & $24.69 \pm 16.16$ & $16.56 \pm 7.87$ & 6.3543 & $<0.0001$ \\
\hline 4000 & $28.75 \pm|5.8|$ & $16.72 \pm 9.56$ & 9.1992 & $<0.0001$ & $29.69 \pm 20.63$ & $17.97 \pm 10.9$ & 7.0592 & $<0.0001$ \\
\hline 8000 & $28.83 \pm 19.37$ & $|5.3| \pm \mid 4.30$ & 7.9843 & $<0.0001$ & $26.43 \pm 19.24$ & $|7.81 \pm| 3.76$ & 5.1759 & $<0.0001$ \\
\hline
\end{tabular}

Notes: Statistical significance, $p<0.05 ;{ }^{*}$ frequency.
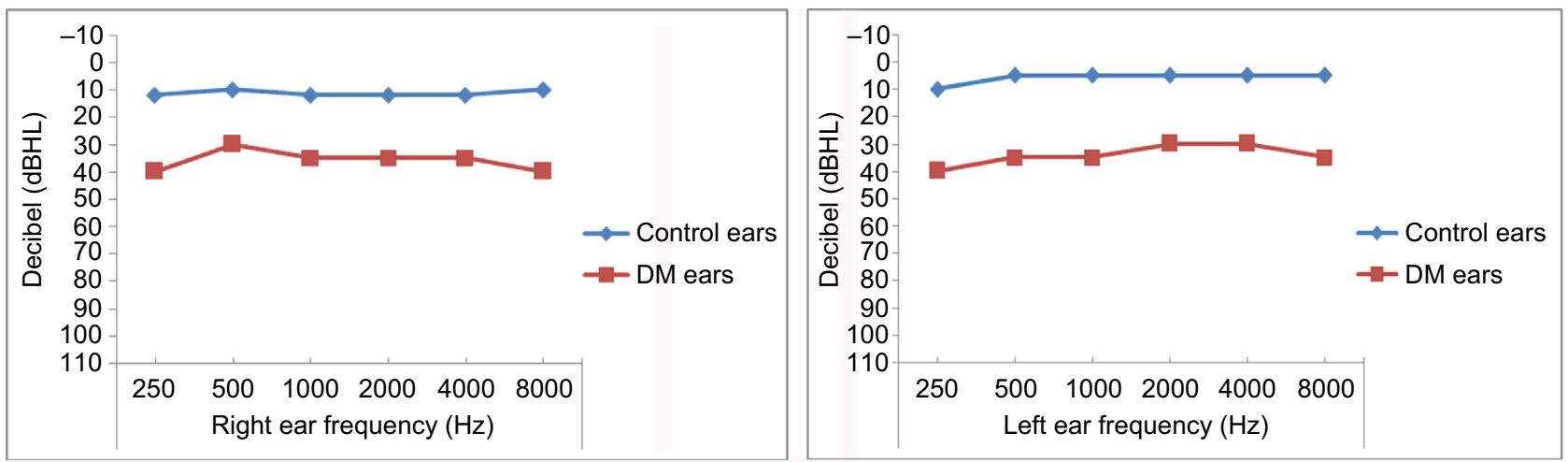

Figure I The audiogram of mean hearing thresholds of DM patients and controls. Abbreviation: DM, diabetes mellitus. 
higher than that reported by Lasisi et $\mathrm{al}^{7}(17.0 \%)$ in Ibadan, Nigeria. Between-survey similarities and differences in inclusion criteria, participants' demographics and clinical profile might explain these observations. While the participants in this study were adults who have had diabetes for 5 years or longer, the Ibadan ${ }^{7}$ report included pediatric subjects with $<5$-year history of diabetes. To enable valid comparisons between the survey results, the authors suggest the standardization and adoption of a standard recruitment procedure during future surveys. The high prevalence of hearing loss among diabetics emphasizes the constant necessity for routine periodic audiometric evaluation among adult diabetics. Future longitudinal studies are needed to assess the temporal profile of diabetes-related hearing loss and inform the frequency of audiometric assessments. The hearing thresholds of the cases compared with controls showed significant difference at all frequencies in both right and left ears, with the cases showing higher thresholds. This is consistent with the findings of Ologe and Okoro ${ }^{8}$ and underscores the constant necessity for periodic otologic screening in all adult diabetics.

The severity of hearing loss among the cases was frequently mild (25.0\%) and moderate (15.6\%); severe $(6.3 \%)$ hearing loss was relatively infrequent. Thus, $21.9 \%$ of patients had moderate to severe hearing impairment, which will add to the burden of their systemic morbidity and adversely impact on their quality of life and performance. ${ }^{18}$

The type-specific prevalence of hearing loss showed a predominance of SNHL over CHL. Microangiopathy and peripheral neuropathy, common in diabetics, might explain this finding. Although a case-control study, the conclusions drawn from this study and the extrapolation of its findings are limited by its hospital-based cross-sectional design, strict age criterion for enrollment and the potential influence of age-related hearing loss. Therefore, the results cannot be generalized to the entire population and do not provide information on the temporal trend. Population-based surveys across all ages, preferably of longitudinal design, are warranted.

\section{Conclusion}

There is high prevalence of hearing loss, predominantly of the sensorineural type, among adult diabetics at UNTH, Enugu. This might have adverse implications for their quality of life. Routine periodic audiometric assessment of adult diabetics is recommended to ensure early detection and timely otologic care.

\section{Disclosure}

The authors report no conflicts of interest in this work.

\section{References}

1. Ginter E, Simko V. Type 2 diabetes mellitus, pandemic in 21 st century. Adv Exp Med Biol. 2012;771:42-50.

2. Seidell JC. Obesity, insulin resistance and diabetes-a worldwide epidemic. Br J Nutr. 2000;83 (Suppl 1):S5-S8.

3. Sierra GN. The Global pandemic of diabetes. Afr J Diabetes Med. 2009;4-8

4. Makishima K, Tanaka AK. Pathological changes of the inner ear and central auditory pathway in diabetes. Ann Otol Rhinol Laryngol. 1971; 80(2):218-228.

5. Jorgensen MB, Buch NH. Studies on inner ear and cranial nerves in diadetes. Acta Otolaryngol. 1961;107:179-182.

6. Smith TL, Raynor E, Prazma J, et al. Insulin-dependent diabetic microangiopathy in the inner ear. J Laryngol Otol. 1995;105:236-240.

7. Lasisi OA, Nwaorgu OGB, Bella AF. Cochleo-vestibular complications of diabetes mellitus in Ibadan, Nigeria. Proceedings of the 17th World Congress of the International Federation of Otorhinolaryngological Societies. Elsevier 2003. International Congress Series 2003;1240:1325-1328.

8. Ologe FE, Okoro EO. Type 2 diabetes and hearing loss in Black Africans. Diabet Med. 2005;22(5):661-667.

9. Ologe FE, Okoro EO, Oyejola BA. Hearing function in Nigerian children with a family history of type 2 diabetes. Int J Pediatr Otorhinolaryngol. 2005;69:387-391.

10. Ma F, Gomez-Marin O, Lee DJ, et al. Diabetes and hearing impairment in Mexican American adults: a population based study. J Laryngol Otol. 1998;112(9):835-839.

11. Cullen JR, Cinnammond MJ. Hearing Loss in diabetes. J Laryngol Otol. 1993;107(3):179-182.

12. Virtaniemi J, Laakso M, Nuutinen JN, Karjalainen S, Vartiainen E. Hearing thresholds in insulin - dependent diabetic patients. J Laryngol Otol. 1994;108(10):837-841.

13. Austin DF, Konrad-Martin D, Griest S, McMillan GP, Fausti S. Diabetesrelated changes in hearing. Laryngoscope. 2009;119(9):1788-1796.

14. Bainbridge KE, Hoffman HJ, Cowie CC. Diabetes and hearing impairment in the United States: audiometric evidence from the National Health and Nutrition Examination Survey, 1999 to 2004. Ann of Intern Med. 2008;149(1):1-10.

15. Diaz de Leon-Morales LV, Jauregui-Renaud K, Gray-Sevilla ME, Hernández-Prado J, Malacara-Hernández JM. Auditory impairment in patients with type 2 diabetes mellitus. Arch Med Res. 2005;36(5):507-510.

16. Hirose K. Hearing loss and diabetes: you may not know what you are missing .Ann Intern Med. 2008;149(1):54-55.

17. Araoye MO. Research methodology with statistics for health and social sciences. Nigeria; Nathadex Ilorin. 2004; 115-129.

18. WHO Report of the Informal Working Group on the Prevention of Deafness and Hearing Impairment Program Planning. WHO/PDH/91, Geneva 1991, Grade of Hearing Impairment 1-24. Available from: http://apps.who.int/iris/bitstream/10665/58839/1/WHO_PDH_91.1.pdf Accessed June 12, 2014.

19. Taylor IG, Irwin J. Some audiological aspects of diabetes mellitus. J Laryngol Otol. 1978;92(2):99-112.

20. Axelsson A, Sigroth K Vertes D. Hearing in diabetes. Acta Otolaryngol Suppl. 1978;356:1-23. 
Diabetes, Metabolic Syndrome and Obesity: Targets and Therapy is an international, peer-reviewed open-access journal committed to the rapid publication of the latest laboratory and clinical findings in the fields of diabetes, metabolic syndrome and obesity research. Original research, review, case reports, hypothesis formation, expert opinion and commentaries are all considered for publication. The manuscript management system is completely online and includes a very quick and fair peer-review system, which is all easy to use. Visit http://www.dovepress.com/testimonials.php to read real quotes from published authors.

Submit your manuscript here: https://www.dovepress.com/diabetes-metabolic-syndrome-and-obesity-targets-and-therapy-journal 